Francisca Neuma Almeida Nogueira ${ }^{1}$

Raquel Maria Rigotto ${ }^{2}$

Ana Cláudia de Araújo Teixeira

\title{
O agronegócio do camarão: processo de trabalho e riscos à saúde dos trabalhadores no município de Aracati/Ceará *
}

The shrimp-farming agrobusiness in the municipal district of Aracati, Ceará, Brazil: labour process and risks to worker's health

\begin{abstract}
${ }^{1}$ Enfermeira do Trabalho, Mestre em Saúde Pública, Coordenadora e Professora do Curso de Graduação em Enfermagem da Faculdade do Vale do Jaguaribe, Aracati, Ceará. Membro do Núcleo Tramas - Trabalho, Meio Ambiente e Saúde para a Sustentabilidade.

${ }^{2}$ Médica do Trabalho, Doutora em Sociologia, Professora do Departamento de Saúde Comunitária da Faculdade de Medicina da Universidade Federal do Ceará, Coordenadora do Núcleo Tramas - Trabalho, Meio Ambiente e Saúde para a Sustentabilidade.

${ }^{3}$ Farmacêutica, Mestre em Saúde Pública, Doutora em Educação, Professora do Departamento de Saúde Comunitária da Faculdade de Medicina da Universidade Federal do Ceará, Membro do Núcleo Tramas - Trabalho, Meio Ambiente e Saúde para a Sustentabilidade. Professora da Escola de Saúde Pública do Ceará.
\end{abstract}

*Artigo resultante da dissertação de Mestrado em Saúde Pública intitulada "O processo de trabalho na Carcinicultura e a saúde-doença dos trabalhadores do município de Aracati/Ceará", defendida por Francisca Neuma Almeida Nogueira, na Universidade Federal do Ceará. Bolsista CNPq.

Pesquisa apoiada pelo CNPq - Processo 480548/2004.

Contato:

Raquel Maria Rigotto

Rua Hermínia Bonavides, 330/702

- Praia do Futuro - Fortaleza/CE 60182260

E-mail:

raquelrigotto@gmail.com

Recebido: 05/09/2008

Revisado: 31/03/2009

Aprovado: 02/04/2009

\section{Resumo}

Embora a carcinicultura seja uma atividade considerada positiva, estudos apontam seus impactos negativos referentes ao trabalhador, ao meio ambiente e ao uso descontrolado dos recursos naturais. Este estudo analisou os empreendimentos de carcinicultura do município de Aracati/Ceará, identificou as inter-relações entre os processos produtivos, o ambiente e a saúde dos trabalhadores e analisou suas implicações para o ambiente e a saúde dos trabalhadores. A metodologia seguiu três fases para realização da pesquisa empírica: aproximação com o concreto do trabalho na carcinicultura; estudo dos processos produtivo; e análise discursiva. Os resultados indicam que a indústria de carcinicultura, no município, composta de 16 estabelecimentos, empregou 1.154 trabalhadores, entre 2005 e 2006, cujo perfil evidencia predominância do sexo masculino, na faixa etária de 22 a 30 anos. O processo de trabalho, geralmente, expõe os trabalhadores a longas jornadas, a intenso esforço físico e posturas inadequadas, à radiação infravermelha e ultravioleta, à inalação de metabissulfito de sódio e gases resultantes de sua diluição em água - registrando um caso de morte por edema pulmonar agudo entre os trabalhadores. As alterações ambientais têm levado à redução de espécies nativas do mangue e à salinização das reservas de água do município.

Palavras-chave: carcinicultura, processo de trabalho, saúde do trabalhador.

\begin{abstract}
Although shrimp-farming is of well-known importance within the agrobusiness market, several studies pointed out its negative impacts on workers, environment and its uncontrolled use of natural resources. This study analysed shrimp-farming companies located in the municipal district of Aracati, in Ceará state, Brazil, identifying interrelations among productive processes, environment and workers' health, and analyzing their implications for the environment and workers' health. The research methodology followed three phases: connection with the concrete work on shrimp-farming, study of productive processes and discourse analysis. Results indicated that the 16 local shrimp-farming industries employed 1.154 workers from 2005 to 2006. Workers' profile indicated a predominance of male gender, concentrated in the age group from 22 to 30 years. The work process, generally, exposed workers to long workdays, to intense physical effort and inadequate postures, to infra-red and ultraviolet radiation, to inhalation of sodium metabisulfit and of the gases resulting from its dilution in water - with one registered case of death among those workers due to acute pulmonary edema. The environmental alterations have been leading to the reduction of native species in the swamp, and to the salinization of the municipal district water reservations.
\end{abstract}

Keywords: shrimp-farming, labor process, worker's health. 


\section{Introdução}

A expansão da carcinicultura no Nordeste brasileiro hoje é expressão de pelo menos três fenômenos que se articulam. O primeiro deles é o declínio dos estoques pesqueiros dos oceanos, em decorrência de sua superexploração, o que tem incentivado o desenvolvimento da aqüicultura. De acordo com dados divulgados pelo Greenpeace Internacional (2008), esta já seria a fonte de $43 \%$ do total de pescados consumidos pelos seres humanos. A produção mundial de camarão cultivado, por exemplo, cresceu de 30.000 toneladas em 1981 para 1,63 milhões de toneladas em 2003.

O segundo elemento são as novas estratégias empresariais de (des)localização no espaço mundial: para garantir competitividade no mercado globalizado, as empresas buscam diferentes estratégias, de acordo com suas necessidades de produção. No caso da carcinicultura, entra em jogo o solo barato, o acesso à água abundante, a fragilidade da legislação e da fiscalização ambiental, o financiamento por bancos públicos, entre outros. Há também uma característica de mobilidade dos empreendimentos, que podem se instalar, usufruir intensivamente dos recursos dos ecossistemas e, uma vez exauridos, abandonar a região para instalar-se em outra (LEROY, 2002; RIGOTTO, 2004).

O terceiro fenômeno que compõe o cenário da carcinicultura é a modernização agrícola, a qual representa a expansão do capitalismo avançado no campo, com reestruturação da produção na agricultura, na pecuária e na aqüicultura - a chamada Revolução Azul. Novos arranjos territoriais produtivos expulsam populações locais, proletarizam e precarizam relações de trabalho, ameaçam a segurança alimentar de comunidades tradicionais (ELIAS; PEQUENO, 2006).

O Brasil se insere com destaque nesta atividade produtiva: em 2003, ocupava o sexto lugar na produção mundial de camarão cultivado, após a China, Tailândia, Vietnã, Indonésia e Índia (ASSOCIAÇÃO BRASILEIRA DE CRIADORES DE CAMARÃO, 2004).

A atividade da carcinicultura no Brasil foi introduzida na década de 1970, no estado do Rio Grande do Norte, e apresenta acelerado crescimento a partir de 1996/1997, com o desenvolvimento tecnológico relacionado ao camarão do pacífico (Litopenaeus vannamei). Assim, entre 1997 e 2003, a produção brasileira de camarão subiu de 3.600 para 90.128 toneladas - o que representa um crescimento de $2.405,0 \%$. Também nesse período, a produtividade cresceu de $1.015 \mathrm{~kg} / \mathrm{ha} / \mathrm{ano}$ para $6.084 \mathrm{~kg} / \mathrm{ha} / \mathrm{ano}$, correspondendo a um aumento de 499,0\%. A área ocupada por viveiros de camarão no Brasil passou de 3.548 ha em 1997 para 16.598 ha em 2004 - uma expansão de 367,81\% (ASSOCIAÇÃO BRASILEIRA DE CRIADORES DE CAMARÃO, 2005).

Em 2003 e 2004, os estados do Rio Grande do Norte e do Ceará, situados no Nordeste do Brasil, foram responsáveis, respectivamente, pela primeira e segunda maior produção de camarão do país. A produtividade no Ceará - $7.676 \mathrm{~kg} / \mathrm{ha} / \mathrm{ano}$ - vem superando a média nacional em 20,0\%, com crescimento de 530 toneladas, em 1997, para 25.915, em 2003 (ASSOCIAÇÃO BRASILEIRA DE CRIADORES DE CAMARÃO, 2004).

No diagnóstico sobre a atividade de carcinicultura no estado do Ceará, em 2004, realizado pelo Instituto Brasileiro de Meio Ambiente (Ibama) ao longo das bacias hidrográficas do Ceará, foram identificadas 237 fazendas de camarão em operação, localizadas em dezoito municípios, ocupando uma área de 6.069,96 ha. O Município de Aracati, no qual foi realizado o estudo, concentra $31,4 \%$ destes empreendimentos, com 54 fazendas em operação, que respondem por $12,0 \%$ da produção, comercialização e circulação de camarão no país.

Tais empreendimentos - assim como os industriais e turísticos de grande escala - são incorporados aos planos de desenvolvimento do governo e anunciados e legitimados junto à sociedade como progresso, fontes de emprego e renda para a população, acenando a bandeira da inserção na modernização.

Por outro lado, as transformações socioambientais trazidas pela carcinicultura têm sido evidenciadas em diversos estudos ao longo dos últimos dez anos, fortemente denunciadas pelas comunidades atingidas e por movimentos sociais. Elas ocupam extensas áreas, anteriormente destinadas à salinas, carnaubais, plantações de cana-de-açúcar e manguezais, as quais são substituídas pela paisagem monótona de numerosos viveiros de camarão que se sucedem. Para isso, extinguem comunidades, expulsam famílias de suas terras e modificam suas formas tradicionais de vida em interação com o ecossistema:

Assim, quando os ecossistemas impactados pela carcinicultura deixam de fornecer elementos ambientais importantes, em destaque os alimentos (mariscos, peixe, caranguejo) e a água, a exploração dos ecossistemas costeiros, pelos que praticavam antes da carcinicultura, e hoje, não tendo outras oportunidades de trabalho, a população se depara com uma situação de insegurança alimentar, configurando a carcinicultura como uma indústria que contribui para o legado de enormes passivos ambientais e dívidas sociais que não condizem com a lucratividade sempre crescente que a atividade proporciona. (BATISTA; TUPINAMBÁ, 2005, p. 5)

Os impactos ambientais desta atividade também têm sido objeto de diversos estudos, que apontam o

[...] desmatamento de manguezal, da mata ciliar e do carnaubal; extinção de setores de apicum; soterramento de gamboas e canais de maré; bloqueio do fluxo das marés; contaminação da água por efluentes dos viveiros e das fazendas de larva e pós-larva; salinização do aqüífero; impermeabilização do solo associado ao ecossistema manguezal, ao carnaubal e à mata ciliar; erosão do taludes, dos diques e dos canais de abastecimento e de deságüe; empreendimentos sem bacias de sedimentação; fuga de camarão exótico para ambientes fluviais e fluviomarinhos; re- 
dução e extinção de habitats de numerosas espécies, extinção de áreas de mariscagem, pesca e captura de caranguejos, disseminação de doenças (crustáceos); [...] (MEIRELES, 2006, p. 83)

Ainda as práticas empresariais e das instituições públicas responsáveis têm sido alvo de críticas. Um significativo exemplo delas é que apenas 49,7\% das fazendas de camarão do Ceará apresentavam Licença de Operação (LO) regular emitida pelo órgão estadual de meio ambiente, no diagnóstico realizado pelo Ibama (INSTITUTO BRASILEIRO DO MEIO AMBIENTE E DOS RECURSOS NATURAIS RENOVÁVEIS, 2005).

Dentre os contaminantes contidos nos efluentes dos viveiros está o metabisssulfito de sódio, cuja utilização na carcinicultura tem início com a atividade de despesca, que é a coleta dos camarões nos viveiros através da abertura das comportas, que são telas de nylon e madeira utilizadas para evitar que os camarões passem para os canais secundários ou braços de rio que circundam os viveiros. A finalidade dessas comportas é abastecer os viveiros quando a salinidade baixa e o nível da água também.

De acordo com Araújo e Araújo (2004), o metabissulfito de sódio (alfa ou "grade food", a denominação depende do fabricante) é um agente oxidante que vem em sacos de Polietileno de $25 \mathrm{~kg}$, em pó cristalino de coloração branca, levemente amarelada, usado para prevenir a formação da melanose (manchas negras ou "black spot”) em camarões. É considerado um forte agente redutor e compete com a tirosina pelo oxigênio molecular.

Em contato com a água, o metabissulfito de sódio, sofre uma reação química e libera o gás dióxido de enxofre $\left(\mathrm{SO}_{2}\right)$, que é considerado de insalubridade máxima pela Norma Regulamentadora NR 15 do Ministério do Trabalho e Emprego quando atinge $4 \mathrm{ppm}$. Os trabalhadores dessa atividade são considerados expostos a grave e iminente risco para sua integridade física, caso a concentração do gás atinja valor superior a 8 ppm (partes do gás por milhão de partes do ar contaminado).

$\mathrm{O} \mathrm{SO}_{2}$ é um gás incolor em condições normais de temperatura, de sabor ácido, odor pungente, sufocante, de enxofre queimando. É facilmente liquefeito quando comprimido e condensa-se na forma líquida à temperatura de $-10^{\circ} \mathrm{C}$. O limite de percepção de odor é em torno de 3 ppm. Combina-se facilmente com a água, formando ácido sulfuroso $\left(\mathrm{H}_{2} \mathrm{SO}_{3}\right)$ e ácido sulfúrico $\left(\mathrm{H}_{2} \mathrm{SO}_{4}\right)$. O $\mathrm{SO}_{2}$ é um gás irritante e seus efeitos são devidos à formação de ácido sulfúrico e ácido sulfuroso ao contato com as mucosas umedecidas, em conseqüência de sua rápida combinação com água, quando ocorre reação de oxidação (ARAÚJO; ARAÚJO, 2004). Os mesmos autores reforçam esta tese quando descrevem a sintomatologia da intoxicação aguda:

A intoxicação aguda resulta da inalação de concentrações elevadas de $\mathrm{SO}_{2}$. A absorção pela mucosa nasal é bastante rápida, e aproximadamente $90 \%$ de todo o $\mathrm{SO}_{2}$ inalado é absorvido na via aérea superior, onde a maioria dos efeitos ocorre. Logo após a absorção, ele é distribuído prontamente pelo organismo, atingindo tecidos e o cérebro. Observa-se irritação intensa da conjuntiva e das mucosas das vias aéreas superiores, ocasionando dificuldade para respirar (dispnéia), desconforto, extremidades arroxeadas (cianose), rapidamente seguidas por distúrbio da consciência. A morte pode resultar do espasmo reflexo da laringe, edema de glote, com conseqüente privação do fluxo de ar para os pulmões, congestão da pequena circulação (pulmões), surgindo edema pulmonar e choque. (p. 6)

Entretanto, as implicações sociais da carcinicultura no Ceará, particularmente no tocante ao trabalho e à saúde, ainda são pouco estudadas. Este estudo pretendeu, assim, descrever o processo de trabalho na carcinicultura e analisar suas implicações para a saúde dos trabalhadores no município de Aracati, no Ceará.

\section{Metodologia}

O estudo constituiu-se em pesquisa qualitativa, de caráter exploratório e descritivo, sobre o processo de trabalho na carcinicultura como modificador do estado de saúde-doença no agronegócio implantado no município de Aracati, Ceará.

Na fase exploratória, foram feitos contatos com informantes-chave, como a agente comunitária de saúde e lideranças locais, e colhidas, ainda, informações sobre a história do município de Aracati e do distrito do Cumbe, na literatura especializada, e dados sobre o perfil socioeconômico e sanitário da população, na Secretaria Municipal de Saúde e no Instituto Brasileiro de Geografia e Estatística (IBGE). Seguiram-se duas etapas em campo:

a) Estudo do processo de trabalho nas empresas de carcinicultura com sede no município de Aracati/Ceará, nas comunidades Cumbe, Canavieira, Vila São José, Alto da Cheia e Lagoa do Mato, através de observação direta, orientada por roteiro específico, com registro fotográfico e coleta de informações junto a técnicos e chefias. O roteiro constou de identificação da empresa, seu histórico organizacional, trabalhadores e relações de trabalho, processo produtivo, organização do trabalho, condições de trabalho, política de atenção à saúde dos trabalhadores e relação com o ambiente. As informações coletadas foram registradas em diário de campo e através de fotografias.

b) Entrevistas semi-estruturadas, que foram levadas a efeito com trabalhadores indicados pelos informantes-chave e que se dispuseram a participar da pesquisa. Elas foram realizadas no local de moradia dos trabalhadores e foram gravadas após assinatura do Termo de Consentimento Livre e Esclarecido pelo entrevistado. O roteiro abrange aspectos da identificação do trabalhador, sua história de trabalho pregressa e atual, percepção da relação entre o trabalho na carcinicultura e sua saúde, implicações do trabalho na carcinicultura para sua qualidade de vida, percepção da relação entre 
a atividade da carcinicultura e o ambiente. As entrevistas foram transcritas e analisadas em diálogo com a pergunta de partida, o marco teórico e as categorias enunciadas pelos entrevistados em seu discurso.

As informações coletadas sobre o processo de trabalho foram sistematizadas e organizadas em fluxogramas e textos descritivos. Os discursos dos entrevistados foram analisados a partir de leituras sucessivas que apontaram cinco eixos temáticos para a categorização sistemática: as relações, as condições e os processos de trabalho; a percepção sobre a saúde no trabalho; a qualidade de vida no ambiente de trabalho e de moradia; danos à saúde relacionados à atividade da carcinicultura e seu significado para os trabalhadores; a percepção dos entrevistados a respeito das alterações ambientais e seus impactos sobre suas vidas.

Este estudo buscou garantir o cumprimento dos preceitos éticos contidos na Resolução 196/96 da Comissão Nacional de Ética em Pesquisa, tendo sido adotados os procedimentos de esclarecimento e consentimento através do Termo de Consentimento Livre e Esclarecido para os entrevistados e Termo de Consentimento e Adesão para os estabelecimentos pesquisados, com aprovação do Comitê de Ética em Pesquisa da Universidade Federal do Ceará.

\section{Resultados e discussão}

Aracati está localizada na região nordeste do estado do Ceará (latitude - $4^{\circ} 33^{\prime} 42^{\prime \prime}$, longitude $-37^{\circ} 46^{\prime} 11^{\prime \prime}$ ) e pertence à mesorregião do Baixo Jaguaribe, situado na microrregião do litoral leste, distando 130 km de Fortaleza, a capital cearense. Com área de $1.428 \mathrm{~km}^{2}$, tem uma população de 67.563 habitantes e densidade demográfica de 47,56 hab/ $\mathrm{km}^{2}$ (IBGE, 2005).

Em Aracati, o setor de carcinicultura compõe-se de uma grande empresa, com faturamento anual em torno de US\$ 18 milhões, a qual chegou a empregar cerca de 3.500 trabalhadores entre 2003 e 2004 - embora, no momento da pesquisa, contasse com 1.040 trabalhadores. Em torno dela estão 14 microempresas, com média de 6 empregados, e uma de pequeno porte, com 30 empregados. Destas, 10 trabalham em regime de "parceria" com a grande empresa, adotam sua tecnologia e dela recebem a pós-larva, a ração para o camarão e outros insumos em troca de um contrato de fidelidade que firma o compromisso de vender o produto final apenas para a grande empresa, uma forma de terceirização das atividades e externalização de custos. Os demais são empreendimentos "independentes", podem negociar sua produção com a empresa que lhes for mais rentável. Tais unidades estão situadas nas localidades Cumbe, Canavieira, Vila São José, Alto da Cheia e Lagoa do Mato.

A atividade de carcinicultura teve início na segunda metade dos anos 1990:
Eles chegaram sem pedir licença, não bateram na nossa porta. Nós fomos ameaçados de todas as formas; os empresários diziam que estavam trazendo o desenvolvimento. Mas, que desenvolvimento é esse? A maioria das comunidades costeiras vive da pesca artesanal... Como se vai viver daqui pra frente? [Liderança Comunitária do Cumbe entrevistada por Queiroz (2007, p. 89-90)]

Além do desejo de integração - ainda que fictícia, como sublinha Bourdieu (1998) - na sociedade moderna, as famílias que viviam da catação de caranguejos e mariscos, da pesca e do artesanato com o labirinto, foram levadas a aderirem ao trabalho na carcinicultura, na medida em que as transformações ambientais por ela produzidas começaram a interferir nas atividades tradicionais e a ameaçar a segurança alimentar das comunidades:

Eu sempre trabalhei com a pesca do caranguejo e era o que mais existia aqui dentro. Agora, porque teve essas mortalidades [de caranguejo] aí, eu acho que em termos de viveiro...[de camarão], aí foi que os mangues foi... Talvez esses produtos que eles [carcinicultores] soltam já foi matando a maioria dos caranguejos. Aí o pessoal se afastou um pouco dos mangues, porque não tinha mais trabalho, e foram se empregando em viveiros de camarão. (Entrevistado C)

Este depoimento reflete a insegurança vivida por moradores e pescadores das áreas atingidas pelo agronegócio, sua dificuldade e seu medo em falar abertamente sobre os danos ambientais, socioeconômicos e culturais causados pela carcinicultura em sua comunidade, especialmente da mortandade ou redução da população de caranguejos pelo uso de produtos químicos como o metabissulfito de sódio, e a destruição dos manguezais, provocando o deslocamento dos caranguejos e outros pescados para regiões mais distantes, deixando-os sem seu sustento diário, antes garantido.

De acordo com pesquisa realizada pelo Ministério do Meio Ambiente/Ibama (INSTITUTO BRASILEIRO DO MEIO AMBIENTE E DOS RECURSOS NATURAIS RENOVÁVEIS, 2005), a atividade de carcinicultura ocupa, no município de Aracati, 0,89 trabalhadores por hectare - taxa relativamente elevada, se comparada a outras localidades. Haja vista estarem ali situadas unidades mais sofisticadas do ciclo de produção, como a produção de larvas e o beneficiamento do camarão, que demandam maior contingente de trabalhadores. Entretanto, ao se considerar que um hectare de manguezal íntegro garante o sustento de 10 famílias, a partir da catação de caranguejos e da mariscagem, e que a carcinicultura destrói o manguezal para construir os viveiros, gerando menos de 1 emprego por hectare, é possível levantar questionamentos sobre a justificativa da relevância do setor para a sociedade, apresentada nos discursos oficiais fundamentados na geração de empregos e em divisas provenientes da exportação.

No período da pesquisa em campo (2005-2006), o município de Aracati contava com 1.154 empregos diretos na carcinicultura, dos quais $76 \%$ dos trabalha- 
dores são do sexo masculino, de acordo com os dados do SIAB/PACS/ACS (2006) e pesquisa direta nas empresas. Sua distribuição por faixa etária mostra importante concentração de jovens - 36\% estão entre os 22 e 30 anos, 29\% têm entre 31 e 40 anos e outros 29\% entre 41 e 50 anos. Apenas $6 \%$ têm idade superior a 51 anos. A empresa de grande porte, via de regra, formaliza o vínculo empregatício através da assinatura da carteira de trabalho, mas nas micros e pequenas empresas há irregularidades:

A empresa tem 30 funcionários, mas a metade é sem carteira assinada. (Entrevistado A)

Eu estava com carteira assinada - foi dado baixa agora há pouco tempo. Porque estava pagando muitos impostos, era uma confusão medonha. (Entrevistado B)

Segundo Batista e Tupinambá (2005, p. 7):

É impressionante que num setor tão organizado como a carcinicultura, não se consiga concretizar um código de conduta pautado pela ética e pela responsabilidade frente às questões sociais e ambientais.

As modificações em seu modo de vida tradicional são percebidas como negativas por alguns moradores das comunidades.

\section{O processo produtivo na carcinicultura e seus riscos à saúde dos trabalhadores}

O processo de produção de camarões em cativeiro envolve três grandes etapas: a produção de larvas de camarão, a engorda dessas larvas até o camarão adulto e o beneficiamento do camarão produzido (Figura 1). No caso em estudo, a primeira e a terceira etapas - que implicam em maiores demandas de tecnologia e de investimento em instalações e equipamentos - são realizadas apenas pela empresa de grande porte. A engorda, que ocorre em viveiros, é realizada pela grande empresa, uma fazenda de 600 hectares, e também por pequenos produtores geralmente a ela subordinados.

\section{a) Primeira etapa: O laboratório de pós-larvas}

A produção de pós-larvas - matéria-prima para os viveiros de engorda - inclui a adaptação dos reprodutores da espécie L. Vannamei, o acasalamento, a desova e a eclosão das larvas - etapa de maturação. Em seguida, essas larvas são cultivadas - etapa de larvinicultura, para serem obtidas as pós-larvas. Para isto, há várias atividades complementares, como cultivo das algas que alimentarão as larvas, laboratório para análise bacteriológica, microscopia e serviços de apoio, como captação e bombeamento de água, conforme retratado na Figura 2.

A maturação tem início em ambiente de confinamento, sem luz natural, no qual machos e fêmeas reprodutores, em resposta ao estresse a que são submetidos, acasalam de forma ininterrupta. Trabalhadores retiram as fêmeas dos tanques para verificar se estão ou não “ovadas" e, após a primeira desova, é retirado um olho da fêmea, no intuito de provocar um desequilíbrio hormonal para que ela ovule ininterruptamente. Quando ocorre a desova, os ovos são coletados e levados para outro ambiente, no qual são lavados e colocados em carboys para o processo de eclosão, que ocorre em 14 horas, liberando os nauplius.

Neste setor há 10 trabalhadores. Os que acompanham as variáveis da adaptação e da desova se organizam em turnos nas 24 horas. O ambiente de trabalho é bastante úmido, quente e com pouca luminosidade para desova, mas cria intenso desconforto térmico para os trabalhadores. A observação permanente do processo e a captura dos ovos exigem posturas forçadas dos trabalhadores envolvendo a flexão do tronco e dos membros inferiores. Deles é exigido rigoroso controle do processo, com registro de dados que permitirão calcular a taxa de acasalamento e o percentual de desova.

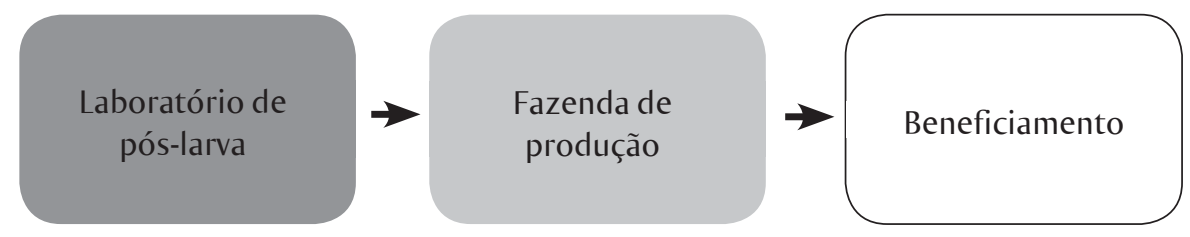

Figura 1 Fluxograma geral ilustrado do processo produtivo na carcinicultura no município de Aracati 


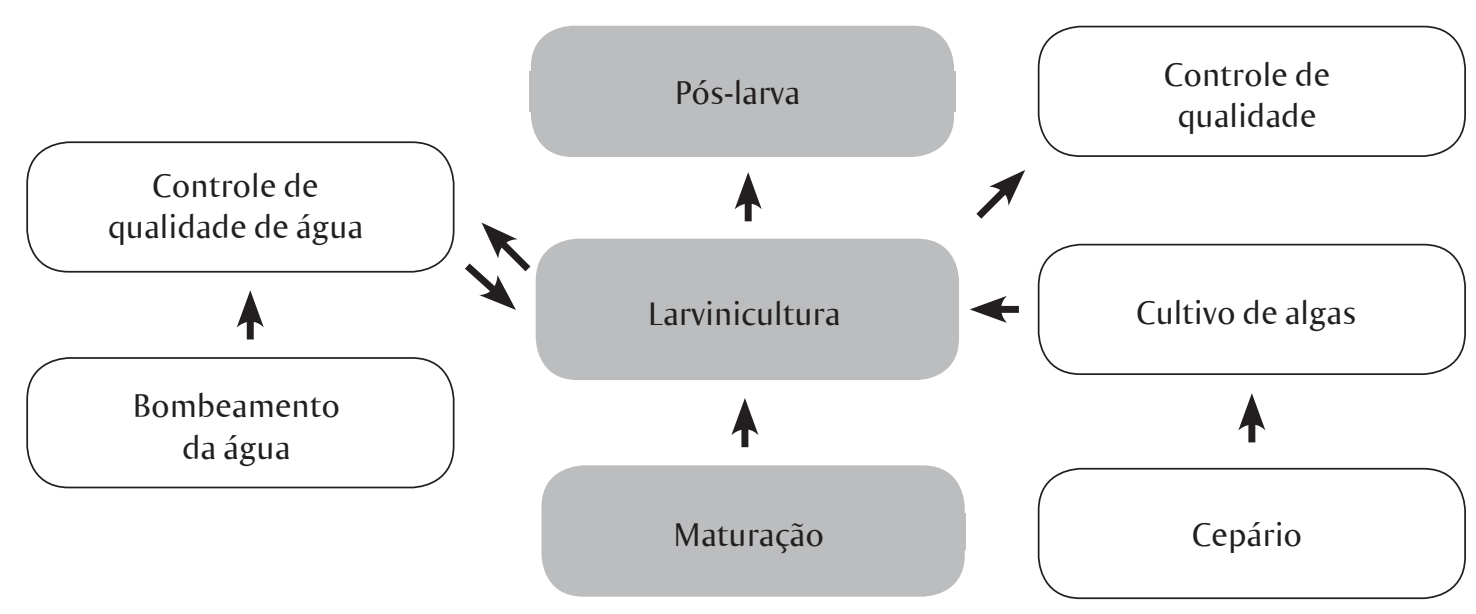

Figura 2 Fluxograma do processo produtivo no laboratório de pós-larva

Então, tem início a etapa de cultivo das larvas, as quais são transferidas para tanques de 25 mil litros de água captada do mar, previamente higienizados com ácidos, cloro e detergentes e preparados com alimentação balanceada à base de microalgas. Após 19 dias, 12 milhões de nauplius atingirão o estágio de produto final - PL-10 ou pós-larva 10.

Os trabalhadores, em número de 26, com quatro do sexo feminino, controlam a concentração de oxigênio, o nível da água, a temperatura, o balanceamento da alimentação e o crescimento das pós-larvas, revezando-se em turnos de 24 horas. Além de acidentes e lesões de pele causadas pelas substâncias químicas utilizadas, há risco de quedas no piso úmido, desconforto térmico, contato com diferentes agentes biológicos, ruído das máquinas, posturas inadequadas e responsabilidade de que todas as variáveis sejam bem observadas e controladas de forma a garantir a produtividade.

A atividade de despesca das pós-larvas, realizada manualmente com o auxílio de uma rede de pesca, dura cerca de 10 horas - período em que o trabalhador fica dentro do reservatório sem poder interromper o trabalho. Sem vestimenta apropriada - normalmente apenas com um calção, entra em contato direto com a água salinizada e com os resíduos alimentares dos nauplius; com parasitos/bactérias e toxinas expelidas pelos nauplius durante seu crescimento nos tanques. Trabalha exposto aos raios solares e a quedas. O manuseio da rede exige esforço repetitivo, postura inadequada do corpo pela curvatura do dorso para arrastar a rede e fadiga pelo intenso esforço físico realizado por período prolongado.

Teve trabalhador lá que não se dava com a água salgada e teve umas coisas no corpo, coceira, essas coisas, micose - já teve. Às vezes saiu mais por causa disso, porque não agüentava o trabalho. (Entrevistado D)
Além de abastecer os viveiros de engorda da própria empresa, as pós-larvas são também vendidas - cada caixa com 7 milhões delas é comercializada por cerca de 10 euros.

Dentro da empresa é preparada também a alimentação das larvas: cepas de Thalassiosiria, fornecidas pela Universidade Federal do Ceará, são cultivadas em meio de cultura de água do mar, com nitrato e fosfato, com temperatura e aeração controladas. À medida que as algas se multiplicam, são semeadas em recipientes progressivamente maiores, na sala de cultivo massivo, na qual também é adotado rigoroso controle da contaminação por microrganismos. A contagem de algas é realizada uma vez ao dia. Sua alimentação ocorre em um período de 3 a 4 horas por dia. Todo o material utilizado é lavado com ácido e cloro.

Esta etapa do processo produtivo é realizada por oito trabalhadores, alguns com escolaridade de nível médio, sob a coordenação de um biólogo. Eles fazem o controle de qualidade do crescimento das algas através de microscópio e a olho nu, acompanhando a modificação da coloração da água contida nos sacos, a qual escurece à medida que as larvas se multiplicam, até atingirem a cor marrom. Também observam o ambiente, verificam se há vazamentos nos sacos de cultivo, aeração inadequada, temperatura etc. Os trabalhadores do cultivo massivo transferem os sacos plásticos para os recipientes de 550 litros de água salgada, acompanham o crescimento das algas e, finalmente, transferem o conteúdo dos recipientes para as piscinas de fibra de vidro.

Durante o processo produtivo, os trabalhadores estão sujeitos: à manipulação de produtos químicos como ácidos e cloro; ao contato com água salina e doce em abundância, podendo se contaminar com bactérias, fungos, parasitas e outros microorganismos; ao desconforto térmico, pela permanência em ambiente refrigerado e com umidade elevada, em contraste com a exposição 
ao sol; à queda de desnível, ao subir nos reservatórios para verificação do desenvolvimento das larvas de algas; a quedas, pela umidade permanente em todas as áreas dessa ala.

O laboratório de análise bacteriológica verifica a qualidade da água utilizada na maturação e na larvinicultura: o auxiliar de laboratório coleta as amostras da água e prepara lâminas com uso de centrífuga e de reagentes químicos para leitura em microscópio ótico. Duas vezes ao dia são colhidas também amostras do nauplius para acompanhamento do crescimento. A jornada de trabalho é de 24 horas, em escala de plantão, com possibilidade de se realizar horas extras.

A água salgada para todos estes processos é captada do mar, na praia de Lagoa do Mato, com equipamentos instalados a 9 metros de profundidade, acionados automaticamente quando o nível da água baixa dentro dos reservatórios da empresa. Um trabalhador é responsável pelo funcionamento ininterrupto do maquinário, exposto a ruído e vibração.

A água captada, armazenada em quatro reservatórios de 250 mil litros - conta-se também com dois reservatórios de 70 mil litros de água doce - é então filtrada por areia grossa, carvão ativado e celulose. Ao final do processo produtivo, a água utilizada passa por uma estação de tratamento e é lançada ao mar.

O setor de bombeamento, responsável pelo suporte à larvinicultura, cuida do fornecimento permanente de água salgada, água doce e oxigênio através de tubulações específicas. A temperatura dos tanques é mantida a partir de gás butano, armazenado no grupo gerador.

O processo de trabalho, organizado em plantões de 24 horas, consta da manutenção do funcionamento dos equipamentos e da resolução de problemas que possam surgir durante a operação do maquinário. Os trabalhadores poderão ter exposição ao gás butano, com riscos de hipóxia e incêndio. Também há ruído excessivo pelo funcionamento das máquinas e desconforto térmico pelo calor excessivo no local, com incidência de raios solares.

Ao final deste processo, as pós-larvas produzidas são transportadas às fazendas de produção para engorda.

\section{b) Segunda etapa: A fazenda de produção}

O processo produtivo nas fazendas (Figura 3) tem início com o povoamento dos viveiros-berçários com pós-larvas que, em seguida à sua maturação, são transportadas para os viveiros de engorda. Após 120 dias, o camarão atinge o tamanho desejado - $15 \mathrm{~cm}$ - e então é feita a despesca e o produto é encaminhado à unidade de beneficiamento - terceira e última etapa. Os viveiros passam então por um processo de desinfecção denominado calagem.

No berçário, que só existe na empresa de grande porte, as pós-larvas ficam em adaptação por 10 a 20 dias, em condições hidrológicas ideais para reduzir perdas. Em seguida, são transferidas para os viveiros de engorda, que são grandes tanques escavados no solo, contendo água de salinidade controlada, equipado com aeradores. Os camarões devem ser alimentados três vezes ao dia - este é o trabalho do arraçoador ou caiaqueiro, que se desloca pelo viveiro remando um bote de fibra de vidro, no qual leva cerca de 80 quilos de ração. Fixadas em 200 a 300 mastros, há bandejas-comedouros, das quais ele deve retirar a ração que sobrou da refeição anterior e abastecer com nova ração.

A atividade envolve esforço físico intenso, exercido em condições climáticas adversas: sol e calor. O trabalhador está exposto também à poeira da ração e à posturas inadequadas para a coluna.

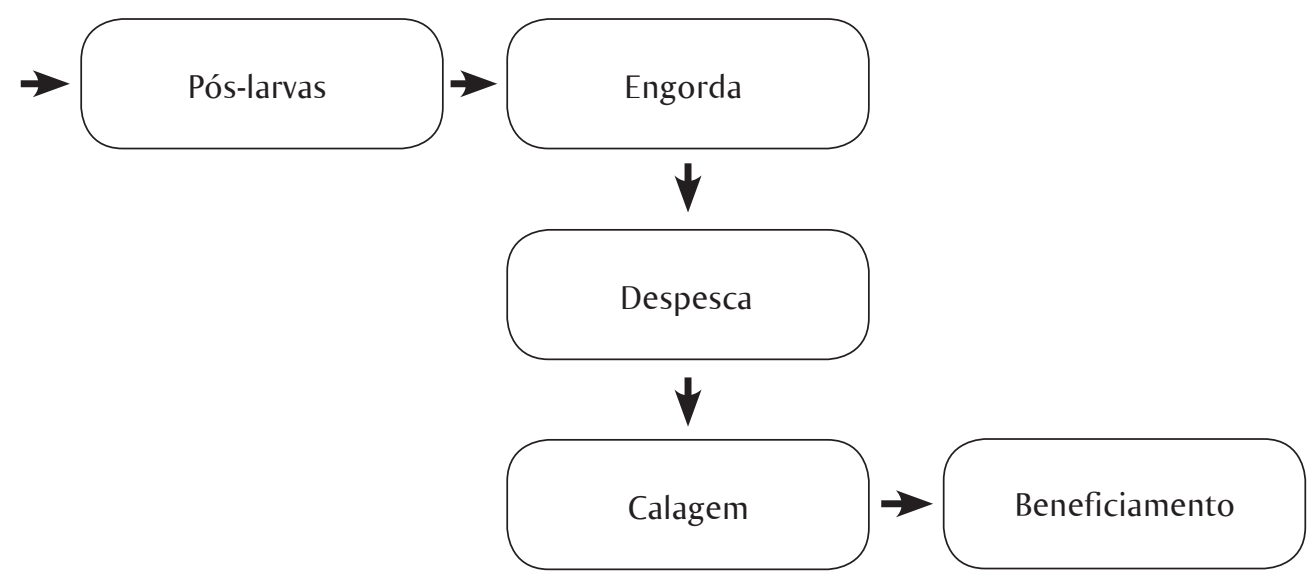

Figura 3 Fluxograma do processo produtivo nas fazendas de engorda do camarão 
O que sempre acontece é sobre coluna, entendeu? O cara trabalha por muito tempo e sempre ele apresenta os sintomas. Os problemas de coluna são mais dos caiaqueiros. (Entrevistado A)

Quando você joga a medida dentro da bandeja aquele pó sobe... É que muitos dizem que dá uma doença do tipo câncer, uma coisa que existe nela... (Entrevistado D)

Os repositores são responsáveis pela manutenção do volume de água dos viveiros e pelo controle de sua aeração. Os teleiros se encarregam da limpeza permanente das telas das comportas dos viveiros, colocadas para impedir a entrada de corpos estranhos nos viveiros. Essa atividade exige habilidade de natação e fôlego profundo, pois esse trabalhador demora para limpar as telas, submerso a uns 3 metros de profundidade.

Em cada uma destas funções, o trabalhador poderá ser exposto à situação de risco como exposição ao sol e calor intensos, afogamento, esforço repetitivo, principalmente na atividade do caiaqueiro, contaminação por vírus, fungos, parasitos e bactérias pelo contato permanente com a água.

Na seqüência do processo de engorda, acontece a despesca, que se caracteriza como o momento em que os camarões são retirados dos viveiros através de rede de pesca colocada na comporta. Eles são jogados vivos em caixas contendo água e metabissulfito de sódio. Em seguida são acondicionados em caixas de isopor com gelo e colocados em caminhões para serem levados ao beneficiamento.

A despesca ocorre à noite para reduzir o estresse dos camarões, geralmente com duração de, pelo menos, 18 horas. A operação não pode ser interrompida, haja vista a drenagem da água do viveiro, normalmente realizada por equipes de trabalhadores treinados nessa atividade. O esforço físico é intenso nessa jornada prolongada: um viveiro pode conter de 5 a 40 toneladas de camarões que precisam ser despescados em poucas horas, resfriados e embalados sem danos. Muitas vezes as condições do trabalhador de alimentação e hidratação em campo são precárias. Há contato direto com a água do viveiro, que concentra restos de ração, fezes e camarões mortos. Manipulam também o gelo e o metabissulfito de sódio.

O metabissulfito de sódio é adicionado na forma de pó cristalino à água para formar solução na concentração de 7 a 9; nessa solução, os camarões ficarão imersos por um período de 12 a 15 minutos. O metabissulfito agente oxidante, usado para prevenir a melanose (manchas negras ou "black spot") em camarões, é considerado um forte agente redutor e compete com a tirosina pelo oxigênio molecular. No momento da reação com a água, libera o dióxido de enxofre $\left(\mathrm{SO}_{2}\right)$ e forma ácido sulfuroso $\left(\mathrm{H}_{2} \mathrm{SO}_{3}\right)$ e ácido sulfúrico $\left(\mathrm{H}_{2} \mathrm{SO}_{4}\right)$. A inalação de concentrações elevadas deste gás irritante provoca efeitos danosos às vias aéreas superiores e, com rápida absorção, causa dispnéia, desconforto, cianose e distúrbio da consciência. Pode ocorrer morte por espasmo reflexo da laringe, edema de glote, edema pulmonar e choque. A pneumonia pode ser uma complicação, bem como a broncoconstrição, especialmente em asmáticos.

Em exposição subaguda e crônica, há registros de bronquite crônica, enfisema pulmonar e infecções respiratórias freqüentes. Podem ocorrer alterações dos dentes (amarelamento do esmalte e erosões dentárias) e distúrbios das gengivas. Distúrbios metabólicos como desordens no metabolismo das proteínas, carboidratos, deficiências de vitaminas B e C têm sido encontrados. É provável que a absorção de grande quantidade de $\mathrm{SO}_{2}$ tenha efeitos hematológicos, produzindo metemoglobina. Níveis de sulfemoglobina de $6 \%$ a $12 \%$ foram encontrados na autópsia de dois trabalhadores que morreram intoxicados. O contato com a pele provoca irritação devido à formação de ácido sulfuroso e suor (INTERNATIONAL LABOUR OFFICE, 1983).

Na região em estudo, foi relatado um caso de óbito pela Delegacia Regional do Trabalho: o trabalhador F.J.P.S., 29 anos, residente no município de Itaiçaba/CE, casado, pai de três filhos, com história ocupacional pregressa de agricultor, auxiliar de servente e auxiliar de topografia. Recentemente trabalhava na equipe de despesca de uma empresa de aqüicultura, sem carteira assinada, com a tarefa de preparar as soluções de metabissulfito de sódio. Chegou a participar de duas despescas, apresentando coceira e tosse, porém na terceira despesca não pôde mais participar, em decorrência do início dos primeiros sintomas e foi despedido em seguida. Os sintomas apresentados depois foram: tosse seca, febre diária matutina $\left(38^{\circ} \mathrm{C} \mathrm{a} 40^{\circ} \mathrm{C}\right)$, manchas vermelhas e coceira na pele, dor de cabeça, dispnéia, astenia, calafrios, anorexia, náuseas e vômitos.

Inicialmente, em uma Unidade Básica de Saúde, recebeu o diagnóstico de infecção de vias aéreas superiores. Duas semanas depois, foi encaminhado ao hospital regional para tratamento de pneumonia lobar. Com agravamento do quadro geral e a dispnéia, foi encaminhado à unidade de tratamento intensivo, inclusive com insuficiência renal grave. A declaração de óbito indicou como causa básica: pneumonia grave da comunidade. Segundo o Comitê Estadual Intersetorial de Vigilância Ambiental em Saúde, da Secretaria Estadual de Saúde, a declaração médica apontou como causa provável da doença a exposição ao metabissulfito de sódio. Entretanto, a Comunicação de Acidente de Trabalho não foi emitida (ARAÚJO; ARAÚJO, 2004).

Nas fazendas de produção do município de Aracati, trabalham 735 trabalhadores, com jornadas de 8 horas diárias que podem ser estendidas, especialmente, quando ocorre a despesca.

Em seqüência à despesca, vem a calagem (Figura 4), que compreende a limpeza do viveiro drenado com a aplicação de 1.000 quilos de cal para cada hectare: os trabalhadores abrem os sacos e, pisando sobre a pasta que cobre o fundo dos viveiros composta de resíduos da alimentação e excreta dos camarões, espalham o pó sobre o solo. O trabalho, realizado sob o sol, exige esforço físico intenso e expõe os trabalhadores à ina- 
lação de poeira irritante para pele e mucosas das vias aéreas superiores.

Oito dias após a calagem, o viveiro está pronto para ser povoado novamente, é reiniciado o ciclo da produção.

\section{c) Terceira etapa: A unidade de beneficiamento}

A unidade de beneficiamento é a etapa final do processo de produção de camarão em cativeiro, realizada em Aracati apenas pela empresa de grande porte. Os camarões provenientes da despesca são higienizados, classificados e congelados em pequenos volumes, em seguida embalados e expedidos, conforme fluxograma apresentado na Figura 5.

Na área de recepção trabalham 120 empregados que se revezam em três turnos de 8 horas diárias. Eles retiram do caminhão, manualmente, as caixas de isopor (70 quilos), levando-as, com auxílio de carrinhos, para a câmara de espera, refrigerada. Em seguida, as caixas são levadas e erguidas até a altura do tanque de higienização, onde são esvaziadas. Os camarões são então lavados com hipoclorito de sódio a 10 ppm. Nesse momento, o camarão é captado por uma esteira que os separa da solução e os coloca na linha de produção, que será descrita mais adiante.

Em suas atividades, os trabalhadores estão sujeitos a choques térmicos pela entrada e saída em ambiente refrigerado e em locais com temperatura ambiente em torno de $38^{\circ} \mathrm{C}$, como é o caso da área de higienização dos camarões. Levantam e transportam peso de forma sistemática e continuada, com risco de queda no piso sempre molhado e escorregadio. Entram em contato com o cloro, seja por via cutânea, seja por inalação de suas névoas. A alimentação da máquina de lavar caixas apresenta perigo de amputação de mão.
No setor de classificação, também chamado linha de produção, é feita a seleção manual entre o camarão e o material que acompanha o crustáceo, de maneira que o produto final esteja totalmente isento de qualquer impureza ou corpo estranho. Em duas esteiras, prossegue o trabalho manual de seleção e controle de qualidade do produto; são considerados: peso, tamanho, uniformidade (integridade), consistência (amolecido ou dentro do padrão para ser comercializado) do camarão. Então são encaminhados à estocagem para congelamento. O camarão que está fora dos padrões de qualidade para exportação é vendido no mercado interno.

Nesta área trabalham 60 empregados, em dois turnos de 12 horas diárias e processam cerca de 75.000 $\mathrm{kg} /$ dia, com esforço repetitivo, muitas vezes realizado com elevação de ombros, tendo em vista as características do equipamento, em ambiente com baixa temperatura, sob pressão de tempo e produtividade. Os trabalhadores, em sua maioria mulheres, permanecem em pé durante toda a jornada, tendo apenas uma hora de intervalo para o almoço e uma rendição por turno para realização das necessidades fisiológicas. São freqüentes as queixas de dores nas pernas e nos braços.

$\mathrm{Na}$ área de congelamento, os 70 trabalhadores levam os carrinhos com as embalagens de 2 quilos para dentro da câmara, a uma temperatura de $-18^{\circ} \mathrm{C}$. A jornada é de 8 horas diárias, com revezamento de turnos. A vestimenta de proteção está disponível, mas nem sempre é utilizada pelos trabalhadores, tendo em vista o intenso ritmo de trabalho, entrando e saindo da câmara. Alguns relatam sinais e sintomas como tontura, falta de ar, sudorese intensa, palidez e desmaios, que caracterizam choque térmico. É considerável também o esforço físico no transporte dos carrinhos com os 75 mil quilos diários de camarão.

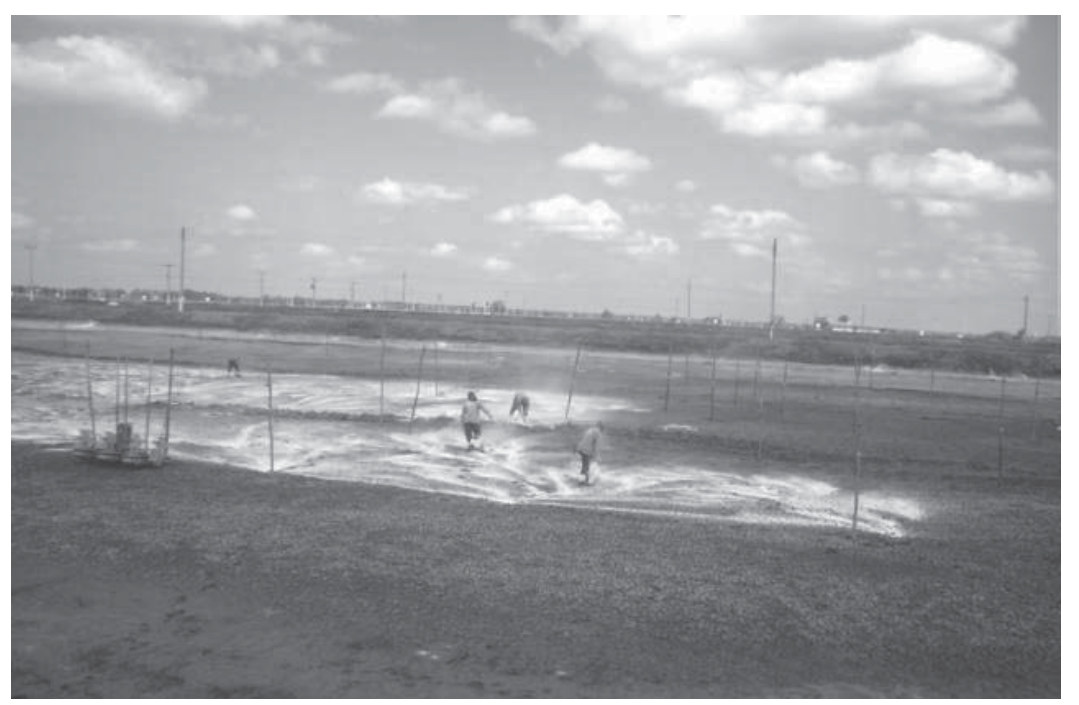

Figura 4 Trabalhadores aspergindo cal em pó no fundo do viveiro drenado 


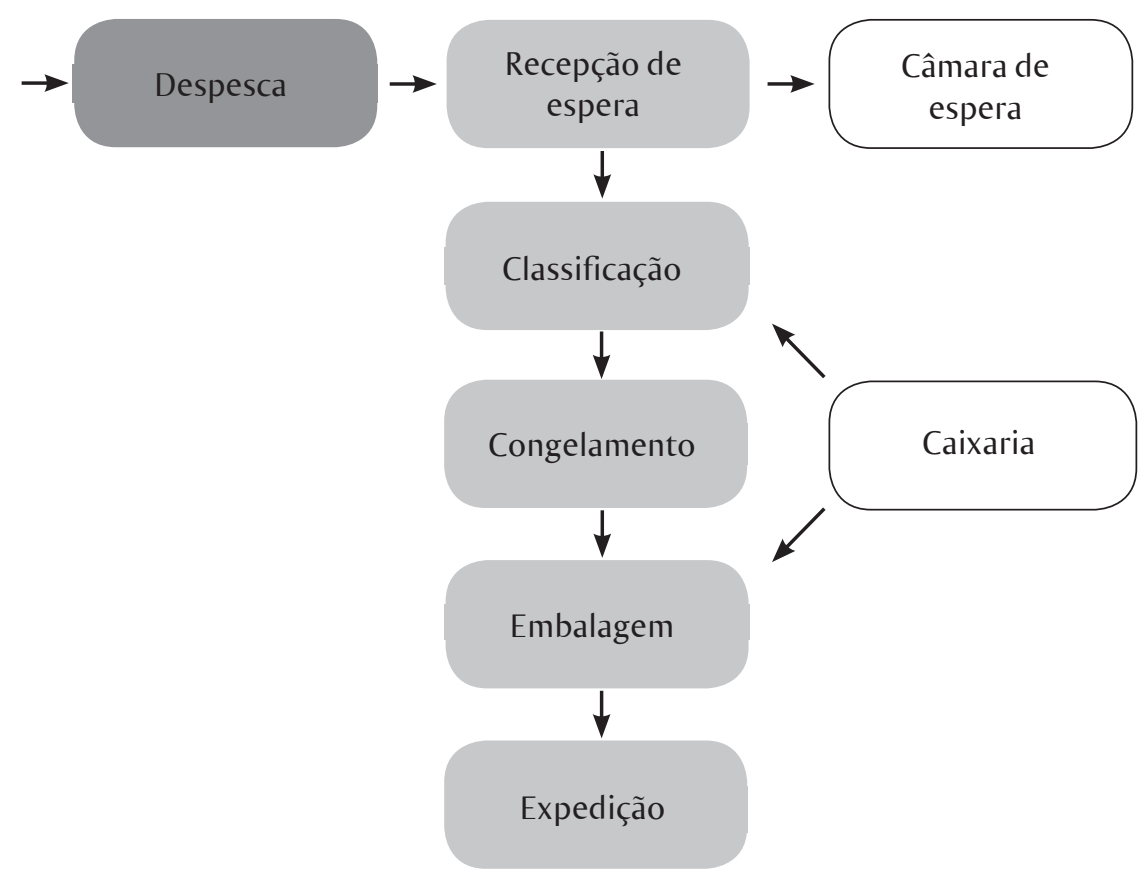

Figura 5 Processo produtivo e de trabalho na Unidade de Beneficiamento

Seis horas após o congelamento, as caixas são retiradas da câmara e levadas para embalagem em caixas de 20 quilos. As caixas são etiquetadas obedecendo aos critérios de cada importador. Estas são empilhadas e transportadas para serem colocadas em outra câmara frigorífica, agora para o congelamento final, e levadas pelos trabalhadores nos ombros. São cerca de 60 trabalhadores submetidos a intenso esforço físico, os quais realizam movimentos repetitivos, em ritmo acelerado e contínuo, em ambiente de baixa temperatura. Todas as atividades são exercidas em pé.

As caixas são dobradas e montadas no setor de caixaria, caracterizado como um serviço de apoio ao processo de acondicionamento do produto, que conta com 42 empregados, em sua maioria mulheres. As atividades e os movimentos são repetitivos, executados sentados, com intervalo apenas para o almoço.

Assim produzido, segue o camarão para consumo no mercado europeu.

\section{Considerações finais}

A implantação da atividade de carcinicultura nos distritos do município de Aracati, além dos impactos ambientais estudados por diversos autores, introduz também riscos relevantes para a saúde dos trabalhadores envolvidos no processo de produção dos camarões. São tempos, saberes, movimentos, valores muito diferentes do "antes" da carcinicultura, que trouxe consigo mudanças no estilo de vida, nos processos de trabalho, no comportamento, entre outros.
Inicialmente atraídos pela perspectiva de inclusão social através do emprego formal, por todo o simbolismo que reveste a carteira de trabalho, e envolvidos pelo discurso do desenvolvimento, os trabalhadores vão, a partir da experiência cotidiana, identificando o outro lado deste tipo de "desenvolvimento": a precária qualidade do emprego, das relações e das condições de trabalho; os riscos à saúde de natureza física, química, biológica e ergonômica; os acidentes, as doenças e o sofrimento seu e dos colegas.

Assim, vão se des-envolvendo deste discurso, especialmente quando se dão conta das perdas em relação ao seu modo de vida tradicional, enquanto pescadores e catadores de caranguejos (TEIXEIRA, 2008): "eu preferia ficar solto, pescando de tarrafa aqui por trás da minha casa, porque tudo é rio... A tarrafa eu compro, mando fazer, aí eu pago. Eu acho que pescar é melhor!" (Entrevistado E). O significado que o mar e o rio têm para eles - ficar solto, bem aqui, num espaço sentido como seu, onde ele é o sujeito - compra, manda fazer, paga.

Mas agora a carcinicultura entra em decadência e talvez estes pescadores possam voltar - não para o seu ecossistema, mas para o que restou dele [a herança maldita de que nos falam Acselrad, Herculano e Pádua, (2004)]: a ganância fez a superpopulação dos viveiros, que fez a infecção pelo vírus da mionecrose, que atrapalhou as exportações (junto com outros fatores...), que fez as fazendas, grandes e pequenas, fecharem em 2007... O capital, usufruindo de sua mobilidade, vai embora. As comunidades ficam lá, tentando resgatar seu sócio-espaço e sua vida. 


\section{Referências}

ASSOCIAÇÃO BRASILEIRA DE CRIADORES DE CAMARÃO. Projeto executivo para apoio político ao desenvolvimento do camarão marinho cultivado. Recife: [s.n], 2004. Disponível em: <http://www. mcraquacultura.com.br/arquivos/Marco04.pdf.> Acesso em: 11 set. 2004.

. Projeto executivo para apoio político ao desenvolvimento do camarão marinho cultivado. Recife: [s.n], 2004. Disponível em: <http://www. mcraquacultura.com.br/arquivos/Marco04.pdf $>$. Acesso em: 12 set. 2005.

ACSELRAD, H.; HERCULANO, S.; PÁDUA, J. A. (Org.). Justiça ambiental: ação coletiva e estratégias argumentativas. In: . Justiça ambiental e cidadania. Rio de Janeiro: Relume Dumará; Fundação Ford, 2004. p. 26-39.

ARAÚJO, F. R.; ARAÚJO, Y. M. G. Metabissulfito de sódio e $\mathrm{SO}_{2}$ : perigo químico oculto para os trabalhadores que realizam a despesca do camarão em cativeiro. Brasília; Ceará: MTE/DRT, 2004. 10p. (Relatório técnico).

BATISTA, P. I. S.; TUPINAMBÁ, S. V. A carcinicultura no Brasil e na América Latina: o agronegócio do camarão. Disponível em: <http://www.rebrip.org. br/projetos/clientes/noar/noar/UserFiles/20/File/ Outras\%20publicacoes/carcinicultura.pdf $>$. Acesso em: 27 set. 2005.

BOURDIEU, P. O poder simbólico. 2. ed. Rio de Janeiro: Bertrand Brasil, 1998.

ELIAS, D.; PEQUENO, R. (Org.). Difusão do Agronegócio e novas dinâmicas socioespaciais. Fortaleza: Banco do Nordeste do Brasil, 2006.

GREENPEACE INTERNACIONAL. La industria acuícola y de engorde: un reto de sostenilidad. Disponível em: < http://www.greenpeace.org/raw/ content/chile/photosvideos/documentos/la-industriaacu-cola-y-de-eng.pdf> . Acesso em: 05 fev. 2008.

INSTITUTO BRASILEIRO DO MEIO AMBIENTE E DOS RECURSOS NATURAIS RENOVÁVEIS. Diagnóstico da carcinicultura no Estado do Ceará. Brasília: DIPRO/DILIQ/DIFAPE/GEREX, 2005.

INTERNATIONAL LABOUR OFFICE. Encyclopedia of occupational health and safety. Genebra: ILO, 1983. v. 2.

LEROY, J.P. et al. Tudo ao mesmo tempo agora desenvolvimento, sustentabilidade, democracia: o que isso tem a ver com você? Rio de Janeiro: Vozes, 2002.

MEIRELES, A.J. A. Danos socioambientais na zona costeira cearense. In: HERCULANO, S.; PACHECO, T. (Org.). Racismo ambiental. Rio de Janeiro: FASE, 2006. p. 73-87.

QUEIROZ, L. S. Na vida do cumbe há tanto mangue: as influências dos impactos socioambientais da carcinicultura no modo de vida de uma comunidade costeira. 2007. 121 f. Dissertação (Mestrado em Desenvolvimento e Meio Ambiente)-Universidade Federal do Ceará, Fortaleza, 2007.

RIGOTTO, R. M. O progresso chegou. E agora? As tramas da (in)sustentabilidade e a sustentação simbólica do desenvolvimento. 2004. 566 f. Tese (Doutorado em Ciências Sociais)-Universidade Federal do Ceará, Fortaleza, 2004.

TEIXEIRA, A.C.A. O Trabalho no mangue nas tramas do (des)envolvimento e da (des)ilusão com "esse furacão chamado carcinicultura": conflito sócioambiental no Cumbe, Aracati, Ceará. 2008. 318 f. Tese (Doutorado em Educação Brasileira)-Universidade Federal do Ceará, Fortaleza, 2008. 